CIVICS EDUCATION AND SOCIAL SCIENSE JOURNAL(CESSJ)

Volume 2 Nomor 1 Bulan Juni 2020

\title{
PERANAN GURU DALAM MEMBENTUK KARAKTER NASIONALISME PADA SISWA SEKOLAH DASARNEGERI GENENGSARI 01 KECAMATAN POLOKARTO KABUPATEN SUKOHARJO TAHUN PELAJARAN 2019/2020
}

\author{
Penulis \\ Aris Kurniawan ${ }^{1}$ \\ Guru MIN Karanganyar \\ Kecamatan Karanganyar, Kabupaten Karanganyar \\ g-mail: arisk718@gmail.com \\ Suyahman ${ }^{2}$ \\ Dosen Program Studi PPKn \\ FKIP-Univet Bantara Sulpharjo \\ Email: suyahman.suyahman@yahoo.com \\ Meidawati Suswandari ${ }^{3}$ \\ Dosen Program Studi PGSD \\ FKIP-Univet Bantara Sulpharjo \\ Email : meidawatis@gmail.com
}

\begin{abstract}
Abstrak
Penelitian ini bertujuan untuk mendeskripsikan peranan guru dalam membentuk karakter nasionalisme pada siswa Sekolah Dasar Negeri Genengsari 01 Kecamatan Polokarto Kabupaten Sukoharjo Tahun Pelajaran 2020.Penelitian ini merupakan penelitian kualitatif. Subjek penelitian ini adalah guruSD Negeri Genengsari 01. Teknik pengumpulan data yang digunakan adalah observasi, wawancara, dan dokumentasi. Hasil penelitian ini menunjukkan bahwa peranan guru dalam membentuk karakter nasionalisme pada siswa SD Negeri Genengsari 01 masih kurang sempurna, hal ini terlihat guru hanya menerapkan 4 peranan saja dari 12 peranan guru di sekolah,sehingga kurangnya tindakan nyata dari guru kepada siswa dalam membentuk perilaku dan sikap nasionalisme. Wujud nyata tersebut tampak siswa kurang memahami bentuk sikap nasionalisme.

Kata kunci: peranan guru, karakter nasionalisme
\end{abstract}

JORNAL PROGDI PPKn, FKIP UNIVET BANTARA SUKOHARJO BEKERJA SAMA DENGAN ASSOSIASI PROFESI PENDIDIKAN PANCASILA DAN KEWARGANEGARAAN (AP3KNI) JAWA TENGAH 
CIVICS EDUCATION AND SOCIAL SCIENSE JOURNAL(CESSJ)

Volume 2 Nomor 1 Bulan Juni 2020

\title{
THE ROLE OF TEACHERS IN FORMING NATIONAL CHARACTERS \\ ON GENENGSARI STATE ELEMENTARY SCHOOL STUDENTS 01 KECAMATAN POLOKARTO SUKOHARJO DISTRICT ACADEMIC YEAR 2019/2020
}

\author{
Authors \\ Aris Kurniawan ${ }^{1}$ \\ Guru MIN Karanganyar \\ Kecamatan Karanganyar, Kabupaten Karanganyar \\ g-mail: arisk718@gmail.com \\ Suyahman ${ }^{2}$ \\ Dosen Program Studi PPKn \\ FKIP-Univet Bantara Sulpharjo \\ Email: suyahman.suyahman@yahoo.com \\ Meidawati Suswandari ${ }^{3}$ \\ Dosen Program Studi PGSD \\ FKIP-Univet Bantara Sulpharjo \\ Email : meidawatis@gmail.com
}

\begin{abstract}
This study aims to describe the role of the teacher in shaping the character of nationalism in Genengsari 01 State Elementary School students in Polokarto District, Sukoharjo District in the 2020 Academic Year. This research is a qualitative study. The subject of this research is the Elementary School teacher Genengsari 01. Data collection techniques used were observation, interviews, and documentation. The results of this study indicate that the role of teachers in shaping the character of nationalism in Genengsari 01 Elementary School students is still imperfect, it is seen teachers only apply 4 roles out of 12 roles of teachers in schools, so that the lack of concrete action from teachers to students in shaping behavior and attitudes nationalism. The real form of it seems that students do not understand the attitude of nationalism.
\end{abstract}

Keywords: teacher's role, nationalism character

JORNAL PROGDI PPKn, FKIP UNIVET BANTARA SUKOHARJO BEKERJA SAMA DENGAN ASSOSIASI PROFESI PENDIDIKAN PANCASILA DAN KEWARGANEGARAAN (AP3KNI) JAWA TENGAH 
CIVICS EDUCATION AND SOCIAL SCIENSE JOURNAL(CESSJ)

Volume 2 Nomor 1 Bulan Juni 2020

\section{PENDAHULUAN}

Pendidikan merupakan prosedur pembaruan tingkah laku seseorang maupun kelompok orang dalam cara mematangkan melalui usaha petunjuk dan penataran maupun pengajaran. Menurut UU No. 20 Tahun 2003 pada pasal 3, menyebutkan bahwa Pendidikan merupakan bentuk usaha sadar dan terencana untuk menciptakan suasana belajar dan proses pembelajaran agar peserta didik mampu mengembangkan potensi dirinya untuk memiliki spiritual keagamaan, pengendalian diri, kepribadian, kecerdasan, akhlak mulia, serta kelebihan yang harus dia perluhkan, masyarakat, bangsa, dan negara. Pendidik merupakan salah satu elemen edukasi menyampaikan konsisten pada pembekalan pada keahlian yang profesional dalam melakukan tanggung jawab. Pengabdian dalam melayani tanggung jawab untuk meningkatkan karakteristik pendidikan sangat dibutuhkan di kehidupan sehari-hari (Arianti, 2019 : 117-134).

Fungsi serta tujuan awal pendidikan nasional, menunjukkan bahwa pendidikan harus di selengarakan secara sistematis agar tujuannya tercapai, contohnya adalah Sekolah Dasar (SD). Hal tersebut berkaitan dengan pembentukkan karakter siswa sehingga mampu bersaing, beretika, bermoral, sopan santun dan berinteraksi dengan masyarakat.Sementara itu guru merupakan suatu profesi, yang berarti suatu jabatan yang memerlukan keahlian khusus sebagai guru dan tidak dapat dilakukan oleh sembarang orang di luar bidang pendidikan(Arifudin, 2015 : 175-186). Jadi guru memiliki peran penting di sekolah yaitu mengajar dan membentuk sikap.

Sikap adalah membentuk kegiatan manusia yang diperoleh suatu perilaku yang melatih generasi yang akan datang. Maksudnya untuk melatih perbaikan diri sendiri berkepanjangan dan membimbing keahlian seseorang menuju hidup yang lebih baik. Sikap adalah keyakinan yang diterjemahkan ke dalam tindakan pada objek yang di inginkan. Sikap didefinisikan oleh Psikologi Sosial sebagai evaluasi positif atau negatif dari reaksi terhadap objek, orang, situasi atau aspek lain, dan memungkinkan kita untuk memprediksi dan mengubah perilaku masyarakat (Palupi \& Sawitri, 2017 : 214-217).

Nasionalisme adalah suatu paham yang berpendapat bahwa kesetiaan tertinggi individu harus diserahkan kepada negara kebangsaan. Perasaan 
CIVICS EDUCATION AND SOCIAL SCIENSE JOURNAL(CESSJ)

Volume 2 Nomor 1 Bulan Juni 2020

sangat mendalam akan suatu ikatan yang erat dengan tanah tumpah darahnya, dengan tradisi-tradisi setempat dan penguasa-penguasa resmi didaerahnya selalu ada di sepanjang sejarah dengan kekuatan yang berbeda-beda (Samsiyah, 2019 : 56-67).

Selain itu, sikap nasionalisme dikaitkan melintasi perilaku penghargaan adat bangsa sendiri, mengawasi warisan adat negara, berjuang, unggul, dan berprestasi, cinta tanah air, melindungi lingkungan, patuh, kesetiaan, menghargai perbedaan budaya dan suku (Abu Bakar, Noor, \&Widodo, 2018 : 42-56).

Sekolah untuk saat ini lebih mengutamakan di bidang akademik dan guru sendiri mulai melupakan bidang-bidang penunjang. Penilaian afektifnya, guru memberi nilai asal-asalan tanpa mengetahui kebenaran dalam afektif siswanya hal tersebut bisa menjadi beban siswa karena siswa dituntut untuk meningkatkan akademiknya. Hal tersebut sebenarnya baik tapi di sisi lain siswa bisa terbebani dengan hal tersebut dan bisa menganggu pembentukan karakter nasionalisme siswa.Sikap nasionalisme sendiri dapat ditumbuh kembangkan melalui pengasuhan orang tua maupun guru. Pengasuhan sebagai upaya orang tua mengajar, dan membimbing untuk semangat cinta tanah air kepada anak-anaknya (Dariyo, 2018 : 326-341). Guru bukan hanya berperan meningkatkan akademik tapi juga guru harus bisa membentuk karakter nasionalisme siswa sesuai dengan tujuan pendidikan Indonesia.

Pernyataan di atas merupakan permasalahan yang sering dihadapi seorang guru berupa penerapan dan penanaman pendidikan karakter belum terlaksana. Pendidikan karakter belum maksimal bisa kita lihat sekarang secara rill atau nyata di kehidupan sehari-hari contohnya saja penanaman sikap disiplin yang kurang terhadap anak, anak SD melakukan perilaku dan ucapan yang kurang sopan terhadap gurunya, anak SD yang kurang menaati peraturan di sekolah, anak SD yang bandel serta sulit di atur dalam melakukan kesalahan, anak SD sudah berpacaran dan lain sebagainya.

Nasionalisme pada siswa untuk saat ini dari tahun ke tahun mengalami penurunan yang sangat mencolok contohnya saja siswa yang sering berkelahi serta tawuran, siswa SD yang sudah melakukan kasus pencabulan, siswa yang tidak hafal teks pancasila, siswa SD yang tidak serus hormat pada sang merah putih, siawa SD yang kurang mengenal pahlawan nasional, siawa yang lebih 
CIVICS EDUCATION AND SOCIAL SCIENSE JOURNAL(CESSJ)

Volume 2 Nomor 1 Bulan Juni 2020

suka produk-produk luar negeri serta wisata-wisata di luar negeri. Hal-hal tersebut membuat kekhawatiran jika siswa sekolah dasar sudah mengenal halhal yang seharusnya tidak mereka lakukan karena melanggar hukum tapi dalam kenyataannya mereka sudah paham dan melakukan hal-hal tersebut maka mereka akan mengoyahkan sikap nasionalisme di lingkungannya yang menyebabkan rusaknya generasi penerus bangsa.

Nasionalisme dipahami sebagai suatu loyalitas tertinggi terhadap bangsa, yang muncul karena adanya kesadaran identitas bersama meskipun berbeda dengan lainnya (Fatmawati \&dkk, 2018 : 80-92). Penanaman dan pembentukan karakter nasionalisme di sekolah saat ini masih kurang, terbukti banyak siswa SD Negeri Genengsari 01 yang tidak menghormati orang yang lebih tua dan mereka sudah berani melecehkan orang yang lebih tua, mereka yang tidak hafal teks pancasila, mereka yang setidaknya hafal lagu Indonesia raya malah kebanyakan suka dengan lagu pop dan dangdut yang sering hadir di layar kaca. Guru yang memiliki peran penting, belum bisa menemukan strategi atau cara yang sesuai untuk membentuk karakter nasionalisme siswa yang sesuai dengan kurikulum yang berlaku saat ini. Sebagai warga negara yang peduli terhadap keutuhan atau kesatuan bangsa tentunya harus memiliki sikap nasionalisme sebagai berikut : 1) Menjaga persatuan dan kesatuan bangsa, 2) Mencintai dan memakai produk-produk dalam negeri, 3) Menjaga nama baik bangsa dan negara, 4) Bersedia membela negara dari ancaman negara lain, 5) Menggunakan bahasa Indonesia dengan baik dan benar (Hestien \& Baehaqi, 2015: 167-180).

Salah satu penghambat atau penghalang dalam pembentukan sikap nasionalisme di sekolah adalah kurangnya penanaman dan pengetahuan terhadap murid tentang pentingnya karakter nasionalisme, atau kurangnya kedekatan guru terhadap lingkungan keluarga atau lingkungan tempat tinggal sang murid dalam membentuk karakter nasionalisme. Sikap nasionalisme di Indonesia pada dasarnya juga tercermin dari ideologi bangsa yang dimiliki, yaitu pancasila. Idiologi Pancasila memiliki lima prinsip nilai yang bersifat dasar dan dijadikan pedoman oleh seluruh warga negara, baik dalam tataran individu maupun kelompok (Ratnasari, 2017 : 144-150). Sehingga penanaman karakter nasionalisme lebih baik di berikan semenjak usia dini, karena pada usia dini akan lebih efektif bagi siswa untuk bekalnya di masa yang akan datang kelak. 
CIVICS EDUCATION AND SOCIAL SCIENSE JOURNAL(CESSJ)

Volume 2 Nomor 1 Bulan Juni 2020

\section{KAJIAN PUSTAKA}

Guru menurut UU no. 14 tahun 2005 "adalah pendidik profesional dengan tugas utama mendidik, mengajar, membimbing, mengarahkan, melatih, menilai, dan mengevaluasi peserta didik pada pendidikan anak usia dini jalur pendidikan formal, pendidikan dasar, dan pendidikan menengah."Dalam dunia pendidikan, istilah guru bukanlah hal yang asing. Menurut pandangan lama, guru adalah sosok manusia yang patut digugu dan ditiru. Digugu dalam arti segala ucapannya dapat dipercaya. Ditiru berarti segala tingkah lakunya harus dapat menjadi contoh atau teladan bagi masyarakat.Perkembangan baru terhadap pandangan belajar mengajar membawa konsekuensi kepada guru untuk meningkatkan peranan dan kompetensinya karena proses belajar mengajar dan hasil belajar siswa sebagian besar ditentukan oleh peranan dan kompetensi guru. Guru yang kompeten akan lebih mampu mengelola kelasnya sehingga hasil belajar siswa berada pada tingat optimal(Syaidah, Suyadi, \& Ani 2018: 185).

Pernyataandi atas dapat disimpulkan bahwa guru merupakan tenaga profesional yang bertanggung jawab kepada siswa untuk mengajarkan atau mendidik dan mengembangkan potensi siswa.

Salah seorang ahli pendidikan Islam yang lain, menyatakan bahwa seorang guru itu harus memenuhi beberapa syarat, yakni : Tujuan, tingkah laku dan pola pikir guru bersifat Rabbani, Ikhlas, Sabar, Kejujuran, Melengkapi diri dengan ilmu dan biasa mengkajinya, Menguasai metode mengajar, Mampu mengelola siswa, Mengetahui kehidupan psikhis para siswa, Tanggap terhadap berbagai kondisi dan perkembangan dunia yang mempengaruhi jiwa, kepercayaan dan bentuk berpikir generasi muda, dan Adil (Alamsyah, $2016: 24$ - 44).

Pernyataan di atas dapat disimpulkan bahwa persyaratan menjadi guru tidak sedikit, hal tersebut wajib dimiliki bila seseorang mau menjadi guru terutama dalam pendidikan formal. dengan melihat syarat-syarat itu bisa dipahami bahwa untuk menjadi guru itu tidak mudah.

Secara luas fungsi pendidik merupakan mengajar. Mengajar sama saja kerangka suatu metode mendidik, menambahkan tekanan, mengapresiasi, memberikan tiruan serta melatih siswa (Darmadi, 2015 : 161-174).

JORNAL PROGDI PPKn, FKIP UNIVET BANTARA SUKOHARJO BEKERJA SAMA DENGAN ASSOSIASI PROFESI PENDIDIKAN PANCASILA DAN KEWARGANEGARAAN (AP3KNI) JAWA TENGAH 
CIVICS EDUCATION AND SOCIAL SCIENSE JOURNAL(CESSJ)

Volume 2 Nomor 1 Bulan Juni 2020

Guru merupakan profesi/jabatan yang memerlukan keahlian khusus sebagai guru. Jenis pekerjaan ini tidak dapat dilakukan oleh sembarang orang di luar bidang kependidikan.Tugas guru sebagai profesi meliputi mendidik,mengajar dan melatih. Mendidik berarti meneruskan dan mengembangkan nilainilai hidup/kepribadian. Mengajar berarti meneruskan dan mengembangkan ilmu pengetahuan dan teknologi. Sedangkan melatih berarti mengembangkan keterampilan-keterampilan kepada peserta didik(Darmadi, 2015 : 161-174).

Pernyataan di atas dapat disimpulkan bahwasanya kewajiban pokok seorang guru adalah mengajar atau mendidik, tetapi guru juga memiliki tugas lain yang tidak kalah penting yaitu di bidang profesi guru dituntut untuk mendidik, mengajar, dan memberi kepelatihan kepada siswa-siswanya

Di sekolah, guru harus dapat menjadikan dirinya sebagai orang tua kedua.Ia harus mampu menarik simpati sehingga ia menjadi idola para peserta didiknya. Pelajaran apapun yang diberikan, hendaknya dapat menjadi motivasi bagi peserta didiknya dalam belajar.Bila seorang guru dalam penampilannya sudah tidak menarik, maka kegagalan pertama adalah ia tidak akan dapat menambahkan benih pengajarannya itu kepada para peserta didiknya(Darmadi, 2015 : 161-174).

Seorang pendidik resmi wajib melengkapi tuntutan sebagai insan yang berkewajiban dalam aspek pelatihan serta dalam masa yang sesuai mereka harus memperluaskan seluruh kewajiban dalam aspek pembelajaran (Syawal Gultom, 2012).

Pernyataan di atas dapat disimpulkan bahwa tanggung jawab seorang guru adalah mampu mengangkat serta menjalankan kewajiban seorang pendidik kepada siswa, wali siswa, maupun warga.

Kecakapan pendidik yaitu kombinasi dari kesanggupan individu, keahlian, teknologi, masyarakat serta akhlaq yang secara kaffah membentuk kompetensi sedang pekerjaan pendidik, yang mencapai kemampuan isi pembelajaran, kejelasan kepada siswa, pelatihan yang membimbing, peningkatan individu serta keahliannya (Murdri, 2010 : 11-124).

Kompetensi pendidik yaitu serangkaian pegetahuan, keterampilan, serta watak yang wajib dipunyai, dimaknai, dikuasai, serta diciptakan oleh pendidik ketika menjalankan tanggung jawab keprofesionalannya. Di samping itu kompetensi pendidik (teacher competency) yaitu kesanggupan seseorang dalam menjalankan tugas-tugas dengan rasa wajib serta patut (Ananda dkk, : 472-489). 
CIVICS EDUCATION AND SOCIAL SCIENSE JOURNAL(CESSJ)

Volume 2 Nomor 1 Bulan Juni 2020

Pernyataan di atas dapat disimpulkan bahwa kompetensi guru yaitu kombinasi atau serangkaian pengetahuan yang wajib di punyai pendidik ketika menjalankan tugas.

Terdapat beberapa peranan pendidik dalam pelatihan yang di kemukakan oleh Arifudin (2015 : 175-186) sebagai berikut : Guru sebagai pembelajaran (Designer of instruction), Guru sebagai pengelola pembelajaran (Manager of instruction), Guru sebagai pengarah pembelajaran

Sikap adalah keyakinan yang diterjemahkan ke dalam tindakan pada objek yang inginkan. Sikap didefinisikan oleh Psikologi Sosial sebagai evaluasi positif atau negatif dari reaksi terhadap objek, orang, situasi atau aspek lain, dan memungkinkan kita untuk memprediksi dan mengubah perilaku masyarakat (Palupi \& Sawitri, $2017: 214-217)$.

Demikian pula dari Palupi \& Sawitri (2017 : 214-217), membagi dua model dari definisi sikap, yaitu (1) Sikap sebagai sebuah kombinasi afektif, kognitif dan konasi (Definisi tiga Komponen), (2) Sikap sebagai penilaian positif atau negative terhadap suatu objek tertentu.

Pernyataan di atas dapat disimpulkan bahwa sikap merupakan keteraturan tertentu dalam hal perasaan maupun cara pandang seseorang yang bersifat positif maupun negatif terhadap kondisi atau keadaan seseorang.

Faktor-faktor yang mempengaruhi Sikap. Sikap adalah pandangan atau perasaan yang di sertai kecenderungan untuk bertindak terhadap obyek tertentu, sikap senantiasa di arahkan kepada sesuatu artinya tidak ada sifat tanpa objek (Umam, 2013 : 79-99).

Demikian pula dari Sembiring (2018 : 108-118), faktor yang mempengaruhi sikap yaitu: Pengalaman pribadi, Pengaruh orang lain yang di anggap penting, Pengaruh kebudayaan, Media masa, Lembaga pendidikan dan lembaga agama, Faktor emosional.

Pernyataan di atas dapat disimpulkan bahwa faktor yang mempengaruhi sikap sangatlah luas seperti dari pengalaman pribadi, pengaruh dari orang lain, pengaruh budaya, dan lain sebagainya.

Pembagian sikap dalam kurikulum 2013, macam-macam pembagian sikap juga di bedakan dalam kurikulum KTSP yang jumlahnya terdapat 18 sikap (Ingsih \& dkk, 2018 : 23-24): 
CIVICS EDUCATION AND SOCIAL SCIENSE JOURNAL(CESSJ)

Volume 2 Nomor 1 Bulan Juni 2020

Religius, yakni ketaatan dan kepatuahan dalam memahami dan melaksanakan ajaran agama (aliran kepercayaan) yang dianut, Jujur yaitu perilaku yang didasarkan pada upaya menjadikan dirinya sebagai orang yang selalu dapat di percaya, Toleransi yaitu sikap dan tindakan yang menghargai perbedaan agama, etnis, dan pendapat, Disiplin yaitu tindakan yang menunjukkan perilaku tertib dan patuh pada berbagai ketentuan dan peraturan, Kerja keras yaitu sikap yang menunjukkan upaya sungguh-sungguh dalam mengatasi berbagia hambatan belajar dan tugas, Kreatif yaitu berpikir dan melakukan sesuatu untuk menghasilkan cara atau hasil baru dari sesuatu yang sudah dimiliki, Mandiri yaitu sikap dan perilaku dan tidak mudah tergantung pada orang lain dalam menyelesaikan tugas-tugas, Demokratis yaitu cara berpikir, bersikap dan bertindak yang menilai sama hak dan kewajiban dirinya dan orang lain, Rasa ingin tahu yaitu sikap upaya mengetahui lebih mendalam dan meluas dari sesuatu yang dipelajari, dilihat dan didengar, Semangat kebangsaan yaitu cara berpikir yang menempatkan kepentingan bangsa dan negara di atas kepentingan dirinya, Cinta tanah air yaitu cara berpikir, bersikap, dan berbuat yang menunjukkan kesetiaan dan kepedulian terhadap bangsa, Menghargai prestasi yaitu sikap dan tindakan yang mendorong dirinya untuk menghasilkan sesuatu yang berguna bagi masyarakat, Bersahabat atau komunikatif yaitu tindakan yang memperlihatkan rasa senang berbicara, bergaul dan bekerja sama dengan orang lain, Cinta damai yaitu sikap yang menyebabkan orang lain merasa senang dan aman atas kehadiran dirinya, Gemar membaca yaitu menyediakan waktu untuk membaca berbagai bacaan yang memberikan kebajikan bagi dirinya, Peduli lingkungan yaitu sikap dan tindakan yang selalu berupaya mencegah kerusakan pada lingkungan alam sekitarnya, Peduli sosial yaitu sikap dan tindakan yang selalu ingin memberi bantuan pada orang lain dan masyarakat yang membutuhkan dan Tanggung jawab yaitu sikap dan perilaku seseorang untuk melaksanakan tugas dan kewajibannya.

Nasionalisme adalah suatu paham yang berpendapat bahwa kesetiaan tertinggi individu harus diserahkan kepada negara kebangsaan. Perasaan sangat mendalam akan suatu ikatan yang erat dengan tanah tumpah darahnya, dengan tradisi-tradisi setempat dan penguasa-penguasa resmi didaerahnya selalu ada di sepanjang sejarah dengan kekuatan yang berbeda-beda (Rahayu, 2017 : 55-65). Pengertian di atas dapat disimpulkan bahwa nasionalisme adalah sebagai paham tentang kecintaan dan loyalitas yang tinggi terhadap bangsanya karena di dalam diri 
CIVICS EDUCATION AND SOCIAL SCIENSE JOURNAL(CESSJ)

Volume 2 Nomor 1 Bulan Juni 2020

telah tertanam identitas yang sama sekaligus paham pendirian dan keyakinan suatu bangsa di mana mereka merasa dalam suatu ikatan kesatuan dan persatuan.

Tujuan nasionalisme, istilah nasionalisme digunakan dalam rentang arti yang kita gunakan sekarang (Subadi \& Zabda, 2016b : 73). Di antara pengunaanpengunaan itu, yang paling penting adalah : Suatu proses pembentukan, atau pertumbuhan bangsa-bangsa, Suatu sistem atau kesadaran memiliki bangsa bersangkutan dan Suatu bahasa dan simbolisme bangsa.

Tujuan nasionalisme sendiri dapat ditumbuh kembangkan melalui pengasuhan orang tua. Pengasuhan sebagai upaya orang tua mengajar, membimbing dan menumbuh kembangkan nilai-nilai positif nasionalisme bagi anak-anak dalam keluarga orang tua berdialog dan mengkomunikasikan nilai-nilai semangat cinta tanah air kepada anak-anaknya (Dariyo, 2018 : 326-341).

Pernyataan di atas dapat disimpulkan bahwa tujuan dari nasionalisme sebagai pemersatu bangsa namun arus globalisasi sekarang menjadi sumber penyakit bagi anak-anak penerus bangsa yang menyebabkan lunturnya nasionalisme maka peran didikan orang tua sejak dini sangat penting demi tertanamnya nasionalisme anak.

Persoalan nasionalisme dan patriotisme di era global sebenarnya bukan hanya masalah yang dialami oleh Indonesia. Amerika Serikat yang merupakan negara adidaya dengan kekuatan politik, ekonomi, budaya, danhankam yang tidak tertandingi pun harus berdaya upaya sekeras-kerasnya dalam membangun semangat nasionalisme dan patriotisme di kalangan warganya. Demikian pula dengan negaranegara lain. Bahkan Malaysia misalnya, beberapa waktu belakangan ini tengah ramai diskusi dan program tentang pembangunan nasionalisme dan patriotisme di negara tersebut (Affan \& Maksum, 2017 : 65-72).

Nasionalisme dipahami sebagai suatu loyalitas tertinggiterhadap bangsa, yang muncul karena adanya kesadaran identitas bersama meskipun berbeda dengan lainnya (Fatmawati \& dkk, 2018 : 80-92).

Penyataan di atas dapat disimpulkan dimana masalah pembangunan nasionalisme saat ini tengah menghadapi tantangan yang berat, maka perlu dimulai upaya untuk kembali mengangkat tema tentang pembangunan nasionalisme. Apalagi di sisi lain, pembahasan tentang nasionalisme di Indonesia justru kurang berkembang. 
CIVICS EDUCATION AND SOCIAL SCIENSE JOURNAL(CESSJ)

Volume 2 Nomor 1 Bulan Juni 2020

Sikap nasionalisme dapat dipahami sebagai suatu loyalitas tertinggiterhadap bangsa, yang muncul karena adanya kesadaran identitas bersama meskipun yang berbeda dengan lainnya (Fatmawati \& dkk, 2018 : 80-92).

Sikap nasionalisme di Indonesia pada dasarnya juga tercermin dari ideologi bangsa yang dimiliki, yaitu pancasila. Idiologi Pancasila memiliki lima prinsip nilai yang bersifat dasar dan dijadikan pedoman oleh seluruh warga negara, baik dalam tataran individu maupun kelompok (Ratnasari, 2017 : 144-150).

Pernyataan di atas dapat disimpulkan bahwa sikap nasionalisme merupakan suatu loyalitas tertinggiterhadap bangsa serta paham (ajaran) untuk mencintai bangsanya sendiri atau suatu sikap cinta tanah air, yang artinya mereka mencintai dan mau membangun tanah air menjadi lebih baik.

Demikian pula dari Hestien \& Baehaqi (2015 : 167-180), sebagai warga negara yang peduli terhadap keutuhan atau kesatuan bangsa tentunya harus memiliki sikap nasionalisme sebagai berikut : Menjaga persatuan dan kesatuan bangsa, Mencintai dan memakai produk-produk dalam negeri, Menjaga nama baik bangsa dan Negara, Bersedia membela negara dari ancaman negara lain dan Menggunakan bahasa Indonesia dengan baik dan benar

Pernyataan di atas dapat disimpulkan bahwa bentuk sikap nasionalisme yang harus di miliki warga negara Indonesia sangat luas seperti mencintai dan mengembangkan budaya sendiri serta mendahulukan kepentingan bangsa di atas kepentingan pribadi. Bentuk-bentuk tersebut selayaknya sikap nasionalisme pada masing-masing warga negara sangat dibutuhkan demi kemajuan bangsa dan negara.

Negara menjadi alat politik sempit dan menimbulkan pertanyaan, mengapa sikap nasionalisme Indonesia justru cenderung semakin rapuh dan ketika negara otoriter Orde Baru telah tumbang dan sistem demokrasi telah mulai terbuka (Hestien \& Baehaqi, 2015 : 167-180). Hal ini disebabkan beberapa faktor diantaranya:

1) Faktor penyebab internal

a) Pemerintahan pada zaman reformasi yang jauh dari harapan para pemuda, sehingga membuat mereka kecewa pada kinerja pemerintah saat ini.

b) Sikap keluarga dan lingkungan sekitar yang tidak mencerminkan rasa nasionalisme dan patriotisme, sehingga para pemuda meniru sikap tersebut. 
CIVICS EDUCATION AND SOCIAL SCIENSE JOURNAL(CESSJ)

Volume 2 Nomor 1 Bulan Juni 2020

c) Demokratisasi yang melewati batas etika dan sopan santun dan maraknya unjuk rasa, telah menimbulkan frustrasi di kalangan pemuda dan hilangnya optimisme, sehingga yang ada hanya sifat malas, egois dan, emosional.

2) Faktor penyebab eksternal

a) Cepatnya arus globalisasi yang berimbas pada moral masyarakat sekarang. Mereka lebih memilih kebudayaan negara lain, dibandingkan dengan kebudayaannya sendiri.

b) Paham liberalisme yang dianut oleh Negara-negara barat yang memberikan dampak pada kehidupan bangsa. Para masyarakat paham liberalisme, seperti sikap individualisme yang hanya memikirkan dirinya sendiri tanpa memperhatikan keadaan sekitar dan sikap acuh tak acuh pada pemerintahan.

Pernyataan di atas dapat disimpulkan bahwa faktor yang mempengaruhi sikap nasionalisme terdiri dari faktor internal dan faktor eksternal, faktor internal meliputi masalah dari dalam seperti masalah politik dalam negeri yang semakin membesar, adanya faktor lingkungan sekitar yang kurang menekankan sikap nasionalisme. Sedangkan dari faktor eksternal meliputi adanya faktor globalisasi yang menyebabkan masyarakat Indonesia cenderung bergaya kebarat-baratan.

\section{METODE}

Pada penelitian ini peneliti menggambarkan pendekatan deskriptif kualitatif. Penelitian kualitatif adalah metode penelitian yang berlandaskan pada filsafat postpositivisme digunakan untuk meneliti pada kondisi obyek yang alamiah dimana peneliti adalah sebagai instrument kunci, pengambilan sampel sumber data dilakukan secara purposive. Penelitian kualitatif berpijak pada paradigm interpretivis yang memiliki desain penelitian berbeda dengan penelitian kuantitatif. Desain penelitian kualitatif diantaranya adalah penelitian naratif, fenomenologi, groundedtheory, etnografi, studi kasus, dan penelitian tindakan (Ihwan Susila, 2015 : 12-23).

Penelitian naratif didefinisikan sebagai "pernyataanlisan atau teks tertulis yang memberikan penjelasan tentang suatu peristiwa atau tindakan atau serangkaian peristiwa atau tindakan, dan kronologis yang terhubung". Penelitian fenomenologimenjelaskan arti dari pengalaman hidup individu atau kelompok. 
CIVICS EDUCATION AND SOCIAL SCIENSE JOURNAL(CESSJ)

Volume 2 Nomor 1 Bulan Juni 2020

Sementara itu, grounded theorybertujuan untuk bergerak di luar deskripsi dan untuk menghasilkan atau menemukan teori yang didasarkan pada data dan pengalaman dari para peserta yang berbagi proses yang sama dan tindakan atau interaksi. Studi kasus melibatkan studi dari sebuah isu yang dieksplorasi melalui kasus-kasus dalam satu pengaturan atau konteks. Sedangkan penelitian tindakan lebih mungkin untuk menyelidiki masalah dalam situasi tertentu di wilayah studi dengan melibatkan peserta. Penelitian sebagai suatu kegiatan yang terorganisir, sistematis, berdasarkan data, dilakukan secara kritis, objektif, ilmiah untuk mendapatkan jawaban atau pemahaman yang lebih mendalam atas suatu masalah.

Penelitian ini akan di lakukan penelitian di SD Negeri Genengsari 01 Kecamatan Polokarto, Kabupaten Sukoharjo. Subyek pada penelitian ini dilaksanakan guru SD Negeri Genengsari 01 Kecamatan Polokarto Kabupaten Sukoharjo. Sedangkan obyek penelitian merupakan permasalahan yang akan diteliti. Obyek penelitian ini adalah Peranan Guru dalam Membentuk Karakter Nasionalisme pada Siswa SD Negeri Genengsari 01 Kecamatan Polokarto Kabupaten Sukoharjo.

Teknik pengumpulan data dalam penelitian ini yaitu dengan wawancara, observasi, dan dokumentasi. Wawancara ialah tanya jawab lisan antar dua orang atau lebih secara langsung. Tujuan wawancara ialah untuk mengumpukan informasi dan bukannya merubah atau mempengaruhi pendapat responden (Ismail, 2011 : 97). Wawancara ini ditunjukkan kepada guru karena dalam penelitian ini lebih megutamakan peranan guru di sekolah dan di kelas.

Observasi merupakan pengamatan dan pecatatan secara sistematis terhadap gejala yang tampak pada obyek penelitian (Ismail, 2011b : 88). Tujuan dari pengambilan data observasi yaitu agar peneliti bisa mengamati guru dalam mengajar di kelas, tujuan lain pengambilan data dengan metode observasi yaitu agar peneliti dapat melihat langsung bagaimana cara guru mengajar dan peneliti dapat menilai cara guru mengajar dalam segi kelengkapan mengajar, model yang digunakan, cara guru mengkaitkan nilai karakter nasionalisme dengan pembelajaran di kelas, interaksi siswa dan lain sebagainya.

Studi dokumentasi merupakan pelengkap dari penggunakan metode observasi dan wawancara dalam penelitian kualitatif. Hasil penelitian dari observasi dan wawancara akan lebih kredibel atau dapat dipercaya kalau didukung oleh sejarah peribadi kehidupan di masa kecil, di sekolah, di tempat kerja, di 
CIVICS EDUCATION AND SOCIAL SCIENSE JOURNAL(CESSJ)

Volume 2 Nomor 1 Bulan Juni 2020

masayarakat dan autobiografi. Hasil penelitian akan lebih kredibel apabila didukung oleh foto-foto atau karya tulis akademik dan seni yang telah ada(Ismail, 2011 b : 107). Pengambilan data dengan metode dokumentasi ini ditujukkan kepada guru dan aktivitas guru dan data sekolah berupa foto sekolahan dengan tujuan bahwa peneliti bisa membuktikan bahwa peneliti ini memang benar telah dilaksanakan di sekolah tersebut dan peneliti bisa memperkuat penelitian ini dengan bukti-bukti tersebut.

Milles dan Huberman (Gumilang, 2016 : 156), secara umum terdapat tiga jalur analis data kualitatif yaitu reduksi data, penyajian data, dan penarikkan kesimpulan. Reduksi data adalah proses pemilahan, pemusatan perhatian pada penyederhanaan, pengabstrakan dan transformasi data kasar yang mucul dari catatan-catatan tertulis di lapangan. Penyajian data adalah kegiatan ketika sekumpulan informasi disusun, sehingga memberi kemungkinan akan adanya penarikkan kesimpulan dan pengambilan tindakan. Penarikkan kesimpulan adalah dimana peneliti terus menarik kesimpulan pada saat di lapangan.

\section{HASIL PENELITIAN DAN PEMBAHASAN}

Dalam dunia pendidikan, istilah guru bukanlah hal yang asing. Menurut pandangan lama, guru adalah sosok manusia yang patut digugu dan ditiru. Digugu dalam arti segala ucapannya dapat dipercaya. Ditiru berarti segala tingkah lakunya harus dapat menjadi contoh atau teladan bagi masyarakat.Perkembangan baru terhadap pandangan belajar mengajar membawa konsekuensi kepada guru untuk meningkatkan peranan dan kompetensinya karena proses belajar mengajar dan hasil belajar siswa sebagian besar ditentukan oleh peranan dan kompetensi guru. Guru yang kompeten akan lebih mampu mengelola kelasnya sehingga hasil belajar siswa berada pada tingat optimal(Syaidah, Suyadi, \& Ani 2018: 185).

Pada pelaksanaan penelitian di Sekolah Dasar Negeri Genengsari 01 Sukoharjo telah ditemukan fakta dan informasi yang bersumber dari observasi dan wawancara. Dan hasil wawancara dengan Guru kelas 1 ibu Sri Waluyani, S.Pd di Sekolah Dasar Negeri Genengsari 01 yang memberikan argumen bahwa :

“...Peran guru dalam menyampaikan tentang pendidikan karakter melalui pengembangan potensi siswa, mendidik serta mengajar. Karena saya disini sebagai motivator dan fasilitator sekaligus sebagai contoh teladan bagi siswa dalam 
CIVICS EDUCATION AND SOCIAL SCIENSE JOURNAL(CESSJ)

Volume 2 Nomor 1 Bulan Juni 2020

kaitannya dengan pendidikan karakter siswa. Selain itu, guru juga harus memberikan contoh tentang pendidikan karakter yang harus dipelajari dan diterapkan siswa". (Wawancara 18 januari 2020)

Mengenai hal tersebut tentang peranan guru yang sebenarnya terbagi menjadi 12 yaitu sebagai pengajar, sebagai fasilitator, sebagai pengelola, sebagai demostrator, sebagai pembimbing, sebagai motivator, sebagai evaluator, sebagai pendidik, sebagai sumber belajar, sebagai penasihat, sebagai inovator, dan sebagai pelatih. Akan tetapi di SD Negeri Genengsari 01 hanya ada 4 yaitu motivator, fasilitator, pengajar, dan pembimbing.

Dengan demikian, hasil wawancara dan observasi di atas penulis dapat menyimpulkan bahwa guru sebagai motivator siswa seharusnya bisa memberikan gambaraan tentang pendidikan karakter supaya siswa bisa memahaminya. Guru juga merupakan tenaga profesional yang bertanggung jawab kepada siswa untuk mengajarkan atau mendidik dan mengembangkan potensi-potensi siswa seperti rasa tanggung jawab, kemandirian, penanaman kerohanian (keagamaan) dan kesehatan jasmani siswa.

Pelaksanaan penanaman sikap nasionalisme akan disebut berhasil itu ditentukan dari berbagai faktor, salah satunya yaitu pemahaman guru tentang sikap nasionalisme.Pemahaman gurutentang sikapnasionalime ini akan digunakan saat guru berinteraksi dengan siswa dalamkegiatanpembelajaran.

Sedangkan Alamsyah (2016 : 24-44), mengatakan bahwa tugas guru cukup berat tapi luhur dan mulia. Karena itu seorang guru disamping memilki jasmani yang sehat dan tidak cacat, ia juga harus memiliki sifat-sifat sebagai berikut: a) Calon sungguh berbakat, b) Pandai bahasa sopan, c) Kepribadiannya harus baik dan kuat, d) Harus disenangi dan disegani oleh anak didik, e) Emosinya harus stabil, f) Pandai menyesuaikan diri, g) Tidak boleh sensitif, h) Harus tenang, obyektif dan bijaksana, i) Harus jujur dan adil, j) Harus susila didalam tingkah lakunya, dan k) Sifat sosialnya harus besar.

Pada pelaksanaan penelitian di Sekolah Dasar Negeri Genengsari 01 Sukoharjo telah ditemukan fakta dan informasi yang bersumber dari observasi dan wawancara. Dalam pelaksanaan pembelajaran di kelas, guru selalu menyelipkannya pada waktu pelajaran. Hal ini diperkuat dengan hasil wawancara dengan Guru kelas 4 ibu Supriyanti, S.Pd SD di Sekolah Dasar Negeri Genengsari 01 yang memberikan argumen bahwa bahwa : 
CIVICS EDUCATION AND SOCIAL SCIENSE JOURNAL(CESSJ)

Volume 2 Nomor 1 Bulan Juni 2020

"Sikap nasionalismesangat penting untukgenerasi-genarasi mendatang, terutama untukanak SD itu dari pendidikan dasar yang mendasari pendidikan selanjutnya. Jadi sikap nasionalisme itu untuk menjaga kelangsungan bangsa dan Negara indonesia.Jadi sangat penting untuk ditanamkan sejak dini”. (Wawancara 18 januari 2020)

Berdasarkan hasil wawancara dan observasi di atas penulis dapat menyimpulkan bahwa dalam membentuk karakter nasionalisme yaitu guru sebagai motivator dan fasilitator namun guru juga berperan aktif pada siswa dan selalu mengingatkan setiap siswa agar siswa menerapkan pendidikan karakter nasionalisme. Pengembangan Sumber Daya Manusia (SDM) melalui pendidikan, guru itu menjadi tulang punggung dan ujung tombaknya dan memiliki peran yang strategis dan signifikan. Karena strategis dan signifikan, tidak mungkin peran ini diberikan kepada orang yang tidak jelas asal-usul dan kualitasnya.

Pelaksanaan penanaman karakter nasionalisme di Sekolah Dasar Negeri Genengsari 01 Sukoharjo telah dilaksanakan melalui berbagai kegiatan, salah satunya yaitu melalui kegiatan pembelajaran, dengan cara sebelum pembelajaran di mulai siswa selalu menyayikan lagu indonesia raya dan hormat kepada bendera merah putih. Sebagai pemberi ilmu, pendidik berkewajiban menyediakan calon penerus negeri yang bisa mendirikan dirinya dan negaranya agar kelangengan serta berkesinambungan kehidupan suatu tanah air. Artinya pendidik berperlakuan seperti kontruksi agar menciptakan bentuk insan yang ingin dibentuk di waktu yang akan datang (The future of the world is the hand of educated people). Guru adalah semua orang yang mempunyai wewenang serta mempunyaitanggung jawab untuk membimbing serta membina murid. Latar belakang pendidikan bagi guru dari guru lainnya tidak selalu sama dengan pengalaman pendidikan yang dimasuki dalam jangka waktu tertentu (Alamsyah, $2016: 24$ - 44).

Hal ini diungkapkan pula oleh guru kelas III Ibu Niken Hastuti yang dalam wawancara menyatakan bahwa :

“...saya selalu menerapkan yang pertama itu, pagi sebelum pembelajaran wajib menyanyikan lagu indonesia raya. Setelah itu doa. Selanjutnnya hormat kepada sang merah putih, supaya tertanam jiwa merah putih dalam diri anak-anak. (Wawancara 18 januari 2020) 
CIVICS EDUCATION AND SOCIAL SCIENSE JOURNAL(CESSJ)

Volume 2 Nomor 1 Bulan Juni 2020

Berdasarkan wawancara yang dilakukan dengan Lendra siswa kelas V menyatakan bahwa :

"Saya tidak paham apa itu karakter nasionalisme, tetapi saat pelajaran bu guru sering mengajak menyanyi lagu indonesia raya, tetapi saya dan teman-teman sebelah kadang ikut menyayi kadang ngak ikut menyanyi, kalo menyanyi sendiri saya juga tidak hafal lagunya, dan karakter nasionalisme aku ngak tau". (wawancara 20 januari 2020)

Berdasarkan hasil wawancara dan observasi di atas penulis dapat menyimpulkan bahwa guru senantiasa selalu memberikan bentuk contoh karakter nasionalisme, sehingga siswa akan terbentuk karakter nasionalismenya. Keberhasilan suatu pendidikan tidak akan terlepas salah satunya dari peran serta guru didalamnya. Ada hubungan yang kuat antara kualitas guru dengankeberhasilan dan kegagalan pendidikan. Bila kualitas guru baik maka pendidikan akan berhasil baik. Begitu juga sebaliknya. Standar kualitas yang dituntut dari seorang guru itu tidak hanya aspek fisik-material saja tetapi juga menyangkutaspek mental-spiritual dan intelektual (Alamsyah, $2016: 24$ - 44).

Pelaksanaan penanaman karakter nasionalisme di Sekolah Dasar Negeri Genengsari 01 selain dilaksanakan melalui kegiatan pembelajaran juga dilaksanakan melalui kegiatan di luar pembelajaran. Pelaksanaan penanaman karakter nasionalisme di luar kegiatan pembelajaran dilaksanakan dengan cara melaksanakan upacara bendera setiap hari senin dan melaksanakan ekstrakurikuler pramuka. Seorang pendidik resmi wajib melengkapi tuntutan sebagai insan yang berkewajiban dalam aspek pelatihan serta dalam masa yang sesuai mereka harus memperluaskan seluruh kewajiban dalam aspek pembelajaran. Pendidik sebagai pengajar berkewajiban memberikan harga-harga serta harokat-harokat oleh penerus muda sehingga menjadi suatu kebebasan serta kelanjutan harga. Apalagi melewati jalan pelatihan, di haruskan terbentuknya harga-harga terbaru (Syawal Gultom, 2012).

Hal ini diungkapkan pula oleh kepala sekolah Ibu Kusrini yang dalam wawancaranya menyatakan bahwa :

“...Iya, kita juga selalu menanamkan rasa memiliki bangsa atau rasa cinta terhadap kebudayan bangsa kita. Misalnya seperti ekstra pramuka, terus upacara. Selain itu juga kegiatan-kegiatan pada hari besar indonesia, seperti misalnya hari 
CIVICS EDUCATION AND SOCIAL SCIENSE JOURNAL(CESSJ)

Volume 2 Nomor 1 Bulan Juni 2020

kartini, kita selalu memakai baju adat bangsa indonesia”. (Wawancara 18 januari 2020)

Berdasarkan hasil wawancara yang dilakukan dengan Yoga siswa kelas IV menyatakan bahwa : "Saat tiba upacara hari senin saya sering terlambat karena ibuk nganternya jam segitu, dan kalo sore jadwal pramuka saya dan teman-teman ngak ikut pramuka karena sama bapak di ikutkan sekolah sepak bola di lapangan sebelah situ”. (Wawancara 20 januari 2020)

Berdasarkan hasil wawancara dan observasi di atas penulis dapat menyimpulkan bahwa dalam menanamkan karakter nasionalisme di luar kegiatan pembelajaran yaitu sekolah juga melaksanakan kegiatan upacara bendera dan juga ekstra kulikuler pramuka supaya siswa bisa memiliki rasa nasionalisme yang tinggi pada bangsanya. Selain itu pendidik yang berpengalaman seharusnya bisa mengangkat dalam menerapkan kewajiban suatu pendidik oleh siswa, wali siswa, warga, tanah air, bangsa, dan panutanya. Kewajiban seorang pendidik yaitu 1) tanggung jawab intelektual diwujudkan dalam bentuk pemahaman teori pengajaran secara terbuka serta secara terpusat, mungkin mengapai pemahaman materi kurikulum mata pelajaran di sekolah serta instansi keilmuan yang menghendel teorinya, hingga pemahaman kepada rangkaian maupun metodologi keilmuannya, 2) Tanggung jawab profesi/pendidikan ditampilkan melewati pengetahuan pendidik kepada siswa, penyusunan serta pemualian pelatihan, ulasan hasil latihan, serta pemerluasan siswa agar mengamalkan sebuah kemampuan yang dia punyai, 3) Kewajiban kemasyarakatan dilihatkan melewati keahlian pendidik berinteraksi serta berbaur kepada siswa, sama-sama kolega pelatih, seorang pelatih, orang tua/wali siswa, serta warga didekatnya, 4) Kewajiban kerohanian serta adab dilihatkan melewati pemaparan pendidik selaku manusia beragama yang wataknya selalu berpegangan dengan bimbingan agama serta keyakinan yang diikutinya dan tidak menyeleweng dari aturan agama serta akhlaq, 5) Kewajiban diri sendiri ditampilkan melewati keahlian pendidik memaknai dirinya sendiri, mengolah dirinya, mengontrol dirinya, serta menghormati dan memperluaskan dirinya ke dalam akhlaq kebatinan.

Berdasarkan analisis di atas yang disesuaikan dengan rumusan masalah yang telah dibuat penulis maka guru memiliki peran yang sangat penting dalam membentuk karakter nasionalisme di Sekolah Dasar Negeri Genengsari 01. Guru harus memiliki kemampuan untuk mewujudkan tujuan Pendidikan Nasional. Hal 
CIVICS EDUCATION AND SOCIAL SCIENSE JOURNAL(CESSJ)

Volume 2 Nomor 1 Bulan Juni 2020

ini sesuai dengan Undang-Undang RI No.20 Tahun 2003 Tentang Sistem pendidikan Nasional Bab II Pasal 3 :

Pendidikan Nasional berfungsi membangun karakter dan menumbuhkan pengetahuan kebudayaan bangsa yang bertujuan untuk berkembangnya potensi peserta didik agar menjadi manusia yang beriman dan bertaqwa kepada Tuhan Yang Maha Esa, sehat, cakap, berakhlak mulia, mandiri, kreatif serta menjadi warga negara yang demokratis serta bertanggung jawab dan berstatus dalam rangka mencerdaskan kehidupan bangsa.

Pembentukan karakter nasionalisme yaitu guru sebagai motivator dan fasilitator namun guru juga berperan aktif pada siswa dan selalu mengingatkan setiap siswa agar siswa menerapkan pendidikan karakter nasionalisme. Hal ini sesuai dengan pendapat Hestien \& Baehaqi (2015 : 167-180), yaitu nasionalisme adalah "perasaan cinta terhadap bangsa dan tanah airnya yang ditimbulkan oleh perasaan tradisi (sejarah, agama, bahasa, kebudayaan, pemerintahan dan, tempat tinggal)". Sikap ini harus dimiliki oleh setiap warga negara sebab dengan adanya sikap cinta tanah air, mereka dapat menjaga dan melindungi negara dan ancaman dalam bentuk apapun. Nilai karakter nasionalis adalah cara berpikir, bersikap, dan berbuat yang menunjukkan kesetiaan, kepedulian, dan penghargaan yang tinggi terhadap bahasa, lingkungan fisik, sosial, budaya, ekonomi, dan politik bangsa, menempatkan kepentingan bangsa dan negara di atas kepentingan diri dan kelompoknya. (Ali \& dkk, 2018 : 42-56).

Berdasarkan hasil di atas maka dapat disimpulkan, nilai nasionalisme harus dimiliki oleh setiap masing-masing siswa karena calon penerus bangsa harus memiliki sikap cinta tanah air, sehingga kelak siswa dapat mempertahankan serta melindungi bangsanya dengan baik. Guru senantiasa selalu memberikan bentuk contoh karakter nasionalisme, sehingga siswa akan terbentuk karakter nasionalismenya. Berdasarkan peneliti, bahwa dalam kegiatan pembelajaran Sekolah Dasar Negeri Genengsari 01 selalu membiasakan siswanya untuk berdoa terlebih dahulu sebelum dimulainya pelajaran, selanjutnya siswa menyanyikan lagu Indonesia raya bersama-sama, serta di lanjutkan hormat kepada sang merah putih. Hal ini sependapat dengan Fatmawati \& dkk (2018: 80-92), mengatakan bahwa nasionalisme dipahami sebagai suatu loyalitas tertinggi terhadap bangsa, yang muncul karena adanya kesadaran identitas bersama meskipun yang berbeda dengan lainnya. 
CIVICS EDUCATION AND SOCIAL SCIENSE JOURNAL(CESSJ)

Volume 2 Nomor 1 Bulan Juni 2020

Berdasarkan hal tersebut dapat disimpulkan bahwa proses penanaman nilai nasionalisme pada siswa harus didasari dengan adanya kesadaran pada diri siswa, maka sewaktu pembelajaran dimulai perlu di selipkan dan diberikan contoh bentuk-bentuk sikap nasionalisme supaya siswa bisa memahami serta mengetahui pentingnya nilai nasionalisme pada diri siswa. Oleh sebab itu pendidik untuk memberikan maupun menanamkannya, maka siswa akan berpikiran bahwasanya seperti inilah bentuk kegiatan nasionalisme yang harus dimiliki, karena terkadang bentuk sikap nasionalisme tidak hanya di lakukan oleh orang yang sudah dewasa alias sudah mempunyai kartu tanda penduduk saja, contoh yang di lakukan seperti taat membayar pajak, patuh dengan undang-undang dan lain sebagainya, melainkan untuk anak usia dini justru malah mempunyai bentuk-bentuk sikap nasionalisme yang dia wajib miliki sebagai warga negara Indonesia sepertihalnya di dalam kegiatan pembelajaran tersebut sangat banyak sekali seperti mengenal jasa-jasa para pahlawan, mempelajari sejarah bangsa indonesia, selalu taat terhadap peraturan undang - undang dan lain sebagainya, hal seperti itulah yang di harapkan wajib di miliki untuk generasi penerus bangsa indonesia.

Dalam penanaman karakter nasionalisme di luar kegiatan pembelajaran yaitu Sekolah Dasar Negeri Genengsari 01 juga melaksanakan kegiatan upacara bendera dan juga ekstra kulikuler pramuka supaya siswa bisa memiliki rasa nasionalisme yang tinggi pada bangsanya. Hal ini sependapat dengan Latief \& dkk (2015 : 1), mengatakan bahwasanya nasionalisme dalam arti sempit adalah suatu sikap yang meninggikan bangsanya sendiri, sekaligus tidak menghargai bangsa lain sebagaimana mestinya. Sikap seperti ini jelas mencerai beraikan bangsa yang satu dengan bangsa yang lain. Keadaan seperti ini sering disebut chauvinisme. Sedang dalam arti luas, nasionalisme merupakan pandangan tentang rasa cinta yang wajar terhadap bangsa dan negara, dan sekaligus menghormati bangsa lain. Menurut Kamus Besar Bahasa Indonesia (2015) bahwa sikap nasionalisme adalah paham (ajaran) untuk mencintai bangsanya sendiri atau suatu kesadaran dari masingmasing anggota suatu bangsa yang secara konkret bersama-sama berjuang untuk mencapai, mempertahankan identitas, intregitas, potensi bangsa, serta memiliki semangat kebangsaan yang tinggi. Penjelasan tersebut dapat diambil poin penting bahwa nasionalisme merupakan ajaran untuk mencintai bangsa sendiri. Sikap nasionalisme adalah bagian dari wujud bela negara yang dilakukan warga negara. Berdasarkan undang-undang dasar 1945 pasal 30 "Tiap-tiap warga negara berhak 
CIVICS EDUCATION AND SOCIAL SCIENSE JOURNAL(CESSJ)

Volume 2 Nomor 1 Bulan Juni 2020

dan wajib ikut serta dalam usaha pembelaan negara”. Syarat-syarat tentang pembelaan negara diatur dengan undang-undang. Jadi sudah pasti mau tidak mau kita wajib ikut serta dalam membela negara dari segala macam ancaman, gangguan, tantangan dan hambatan baik yang datang dari luar maupun dalam (Hestien \& Baehaqi, 2015 167-180).

Jadi dapat disimpulkan bahwa Sekolah Dasar Negeri Genengsari 01 sudah melakukan penanaman karakter nasionalisme di luar kegiatan pembelajaran. Contohnya saja sekolah telah melaksanakan kegiatan-kegiatan di luar pembelajaran seperti upacara pada hari senin serta upacara dalam memperingati hari-hari nasional tertentu hal ini merupakan bentuk penanaman sikap nasionalisme pada diri siswa karena upacara merupakan suatu hal bentuk memperingati suatu kejadian seprti kejadian yang dimiliki warga negara indonesia yang telah dulu mengalami penjajahan serta pasang surut sampai negara ini merdeka, maka dengan bentuk seprti itulah kegiatan upacara di tanamkan supaya siswa generasi penerus bangsa juga paham maksut dan tujunannya, selanjutnya juga melaksanakan ekstrakulikuler pramuka selalu juga di laksanakan untuk membentuk kedisiplinan serta kemandirian anak, karena di situ siswa diajarkan salah satu bentuk rasa cinta kepada tanah air.

\section{KESIMPULAN}

Berdasarkan hasil penelitian dan pembahasan dalam mengidentifikasi Peranan Guru dalam Membentuk Karakter Nasionalisme pada Siswa Sekolah Dasar Negeri Genengsari 01 Kecamatan Polokarto Kabupaten Sukoharjo tahun 2020 harus di lakukan dengan tindakan nyata dalam bentuk sikap, perilaku, dan perbuatan yang mencerminkan sikap nasionalisme.Dari 12 pernanan guru di sekolah, tetapi hanya ada 4 aspek peranan guru yang di terapkan yaitu : 1) peran guru sebagai pengajar yang artinya guru membentuk karakter nasionalisme siswa dengan cara menyelipkannya pada saat waktu pembelajaran seperti berdoa sebelum dimulainya pelajaran, menyanyikan lagu indonesia raya, hormat pada sang merah putih, 2) peran guru sebagai pembimbing yaitu dalam kegiatan di luar pembelajaranpun juga di laksanakan seperti mengikuti upacara bendera pada hari senin maupun upacara bendera pada hari-hari besar nasional, kemudian melaksanakan ekstra kulikuler pramuka, kemudian memakai baju kebaya pada saat 
CIVICS EDUCATION AND SOCIAL SCIENSE JOURNAL(CESSJ)

Volume 2 Nomor 1 Bulan Juni 2020

memperingati hari kartini, 3) peran guru sebagai fasilitator yang artinya yaitu guru hanya menyiapkan semua kebutuhan dalam belajar seperti mebuat foto para pahlawan serta peta wilayah indonesia, 4) peran guru sebagai motivator yang artinya yaitu guru memberikan motivasi kepada siswa seperti saat setelah pembelajaran sudah selesai guru menyampaikannya kepada siswa. Dengan hal tersebut sekolah sudah menerapkan bentuk sikap nasionalisme pada diri siswa di sekolah namun guru harus lebih memperhatikan dan meningkatkan peranan dan metode guru dalam menanamkan karakter nasionalisme pada siswa. Hal tersebut perlu juga di terapkan oleh siswa ketika di rumah maupun di lingkungan manapun dia berada, terutama bagi orang tua di rumah harus bisa mencontohkan serta menanamkan bentuk sikap nasionalisme pada siswa dengan baik dan benar supaya siswa benar-benar tertanam sikap nasionalismenya. dan orang tua siswa pun bisa melakukan penanaman karakter nasionalisme itu dengan melalui pembiasaan, melalui keteladanan, dan melalui penghargaan serta hukuman pada anak yang kurang tepat perilakunya dengan sifat yang edukatif.

\section{REFERENSI}

Abu Bakar, Kosasih Ali, Idris H.M. Noor, and Dan Widodo. 2018. "Nurturing Nationalism Character Valuesat the Primary Schools in Jayapura, Papua." Cakrawala Pendidikan 37(1): 42-56.

Affan, Husein, and Hafidh Maksum. 2017. "Membangun Kembali Sikap Nasionalisme Bangsa Indonesia Dalam Menangkal Budaya Asing Di Era Globalisasi." Jurnal Pesona Dasar 3(4): 65-72.

Alamsyah, Yosep Aspat. 2016. "Expert Teacher (Membedah Syarat-Syarat Untuk Menjadi Guru Ahli Atau Expert Teacher)." Jurnal Pendidikan dan Pembelajaran Dasar 3(1): $24-44$.

Ananda, Fauzi, Ali Imran Sinaga, and Indra Jaya. "Implementasi Kompetensi Pedagogi Guru Fikih Mas YMPI Seitualang Raso Kota Tanjungbalai." : 472-89.

Arianti. 2019. "Peranan Guru Dalam Meminimalisir." DIDAKTIKA : Jurnal Kependidikan 12: $117-34$.

Arifudin, Iman Syahid. 2015. "Peranan Guru Terhadap Pendidikan Karakter Siswa Di Kelas V Sdn 1 Siluman.” Jurnal Ilmiah Pendidikan Guru Sekolah Dasar 2(2): 17586. 
CIVICS EDUCATION AND SOCIAL SCIENSE JOURNAL(CESSJ)

Volume 2 Nomor 1 Bulan Juni 2020

Dariyo, Agoes. 2018. "Peran Pengasuhan Otoritatif Orangtua Untuk Menumbuhkembangkan Sikap Nasionalisme Dan Patriotisme Remaja Dalam Kerangka Ketahanan Nasional." 24(3): 326-41.

Darmadi, Hamid. 2015. "MENJADI GURU PROFESIONAL Diperbincangkan, Karena Guru Merupakan Sumber Kunci Keberhasilan Pendidikan . Didik Yang Menyangkut Berbagai Aspek Yang Bersifat Manusiawi Yang Unik Dalam.” Jurnal Edukasi 13(2): $161-74$.

Fatmawati, Laila, Rani Dita Pratiwi, and Vera Yuli Erviana. 2018. "Pengembangan Modul Pendidikan Multikultural Berbasis Karakter Cinta Tanah Air Dan Nasionalis Pada Pembelajaran Tematik The Development of Multicultural Education Modules Based on Patriotism and Nationalism Character on Thematic Learning." Jurnal Pendidikan \& Kebudayaan Vol. 8(1): 80-92.

Gumilang, Galang. 2016. "Metode Penelitian Kualitatif Dalam Bidang Bimbingan Dan Konseling." Jurnal Fokus Konseling 2(2): 156. http://ejournal.stkipmpringsewulpg.ac.id/index.php/fokus/a.

Hestien, Erwinda, and Dikdik Baehaqi. 2015. "Sikap Nasionalisme Anggota Karang Taruna Desa Karanglo Argomulyo Sedayu Bantul Yogyakarta." Sikap Nasionalisme Anggota Karang Taruna Desa Karanglo Argomulyo Sedayu Bantul Yogyakarta 4(2): $167-80$.

Ihwan Susila. 2015. "Pendekatan Kualitatif Untuk Riset Pemasaran Dan Pengukuran Kinerja Bisnis." Benefit Jurnal Manajemen dan bisnis 19(1): 12-23. http://journals.ums.ac.id/index.php/benefit/article/view/1413/967.

Ingsih, Kusni, Juli Ratnawati, Imam Nuryanto, and Sih Darmi Astuti. 2018. Pendidikan Karakter Alat Peraga Edukatif Media Interaktif. Yogyakarta: Deepublish ( Group Penerbit Cv Budi Utama ).

Ismail. 2011a. Penelitian Pendidikan. JL.Letjen Sujono Humardani No.1 Kampus Jombor: Univet Bantara Press.

_ 2011b. Penelitian Pendidikan. Sukoharjo: Univet Bantara Press.

Murdri, M. Walid. 2010. “Kompetensi Dan Peranan Guru Dalam Pembelajaran.” Falasifa 1 No.1: 111-24.

Palupi, Tyas, and Dian Ratna Sawitri. 2017. "Hubungan Antara Sikap Dengan Perilaku Pro-Lingkungan Ditinjau Dari Perspektif Theory Of Planned Behavior Relationship Between Attitude And Pro-Environmental Behavior from the Perspective of Theory of Planned Behavior Perilaku Pro-Lingkungan." Proceeding Biology Education Conference 14: 214-17. 
CIVICS EDUCATION AND SOCIAL SCIENSE JOURNAL(CESSJ)

Volume 2 Nomor 1 Bulan Juni 2020

Rahayu, Sinta. 2017. "Journal of Indonesian History." Konflik Rasial Antara Etnis Tionghoa Dan Pribumi Di Surakarta 6(1): 55-65.

Ratnasari, 2017. 2017. "Proses Penanaman Sikap Nasionalisme Dalam Ibu Pawiyatan Yogyakarta." Jurnal Moral Kem 12: 144-50.

Samsiyah, Ivan Prapanca Wardhana dan Siti. 2019. "Analisis Buku Teks Sejarah SMA Materi Nasionalisme Dengan Pendekatan Teori Nasionalisme Hans Kohn.” Historika 22(2): 58-67.

Sembiring, Dinaria br. 2018. "Pengaruh Sikap Kerja Dan Motivasi Kerja Terhadap Kinerja Dosen Di Yayasan Perguruan Nasional Medicom.” Teknik Informatika Unika St. Thomas 03(2): 108-18.

Subadi, Tjipto, and Sutan Zabda. 2016. Pendidikan Kewarganegaraan (Civic Education). Sukoharjo: Cv.Jasmin.

Syaidah, Umu, Bambang Suyadi, and Hety Mustika Ani. 2018. "Pengaruh Kompetensi Guru Terhadap Hasil Belajar Ekonomi Di Sma Negeri Rambipuji Tahun Ajaran 2017/2018." JURNAL PENDIDIKAN EKONOMI: Jurnal Ilmiah Ilmu Pendidikan, Ilmu Ekonomi dan Ilmu Sosial 12(2): 185.

Syawal Gultom. 2012. "Pengembangan Profesi Guru." Kementerian Pendidikan dan Kebudayaan: 2012.

Umam, Aguswan. 2013. "Pentingnya Memahami Sikap Terhadap Membaca Pada Siswa Dalam Pembelajaran Bahasa." English Education: Jurnal Tadris Bahasa Inggris IAIN Raden Intan 5(1): 79-99. 